insufficient to enable the active treatments to be compared. Acupuncture and nicotine gum were effective in helping smokers to stop smoking during the first month but did not reduce the tendency to relapse after that time.

The subjects in our trial did not take the initiative in coming to a clinic to stop smoking but were invited to take part. This may explain our low long term rate of success compared with that of withdrawal clinics.

We thank the Haut Comité d'Aide à la Lutte Contre le Cancer, France, for financial support and A B Leo and Co, Sweden, for financial support and for supplying the gum. We are indebted to Robert Molimard for participation, to Catherine Gros, Gérard Lavianne, and Benoit Ponsot for practical help, and to Susheela Fallah for technical help.

1 Lamontagne Y, Annable L, Gagnon MA. Acupuncture for smokers: lack of long-term therapeutic effect in a controlled studv. Can Med Assoc $\mathcal{F}$ 1980;122:787-90.

2 Cottraux JA, Harf R, Boissel JP, Schbath J, Bouvard M, Gillet J. Smoking cessation with behaviou therapy or acupuncture-a controlled study. Behav Res Ther 1983;21:417-24.

3 Hughes JR, Miller SA. Nicotine gum to help stop smoking. JAMA 1984;252:2855-8.

4 Anonymous. Nicotine chewing gum [Editorial]. Lancet 1985; ; 320-1.

5 Clavel F, Benhamou S. Nicotine chewing gum in general practice. Br Med f 1984;289:1308.

(Accepted 7 August 1985

Unité de Recherches en Epidémiologie des Cancers, Institut National de la Santé et de la Recherche Médicale, Institut Gustave Roussy, 94805 Villejuif, France

FRANCOISE CLAVEL, PHD, epidemiologist

SIMONE BENHAMOU, MSC, epidemiologis

Département de Statistique Médicale, Institut Gustave Roussy

ASSUMPTA COMPANY-HUERTAS, MD, epidemiologist

ROBERT FLAMANT, MD, epidemiologist (also at Institut National de la Sante et de la Recherche Médicale)

Correspondence and requests for reprints to: Dr Clavel.

\section{Squash rackets: a survey of eye injuries in England}

With the increasing popularity of the game of squash rackets over the past 15 years there has been a corresponding awareness by ophthalmologists in Western countries of the increased number of ocular injuries. In response to a need for more information on the extent of injuries to the eyes the Squash Rackets Association set up a working party, which carried out a survey of eye injuries sustained during squash from October 1982 to March 1983.

\section{Subjects, methods, and results}

Simple reporting cards were used asking ophthalmologists whose names were on the list of the Faculty of Ophthalmologists in England to report any ocular injury sustained from squash during the six month survey period and also to ask their local accident and emergency department to report similarly when appropriate, the ophthalmologist acting as collator of the reporting cards The reporting card was deliberately brief and covered only the following aspects of the injury: date, age, sex, nature of injury, whether spectacles or eye protectors were worn, and cause of injury (racket, ball, or other).

A total of 339 players ( 278 men and 61 women) were reported with injuries to the eye and adnexae over the six month survey period. The youngest player was aged 7 and the oldest 61 . Most of the injured players (251 out of 339) were aged 20 39.

Most injuries were caused by the ball (235 out of 339), but the racket caused 103 injuries and collision with the wall of the court caused three. Reports of injuries were received from many places in England, but those from areas of dense population and resorts on the south coast predominated.

The table shows the detailed nature of the injuries to the ocular tissues. The concussive nature of most injuries was reflected in the large number of hyphaemas (147) and retinal damage (33) - that is, haemorrhage, oedema, and detachmentwhereas there were only three penetrating injuries.

\section{Comment}

Recent reports of the nature of injuries to the eyes sustained during the game of squash have come from North America, Britain, Australia, and France, ${ }^{1-4}$ and from these reports the squash ball was consistently recorded as the most common cause of injury. In our survey injuries caused by balls outnumbered those caused by rackets by over two to one ( 233 caused by balls and 103 by rackets). The severe concussion injuries that caused retinal damage and the penetrating injuries may have caused some degree of permanent visual impairment; 40 out of 339 players had such injuries.
Detailed nature of injuries to ocular tissues *

\begin{tabular}{|c|c|c|}
\hline Tissue & Injury & No of injuries \\
\hline Orbit & Fractures & 3 \\
\hline Eyelids & $\left\{\begin{array}{l}\text { Lacerations } \\
\text { Bruising }\end{array}\right.$ & $\begin{array}{l}50 \\
40\end{array}$ \\
\hline Conjunctiva & $\left\{\begin{array}{l}\text { Haemorrhage } \\
\text { Lacerations }\end{array}\right.$ & $\begin{array}{r}18 \\
4\end{array}$ \\
\hline Cornea & $\left\{\begin{array}{l}\text { Abrasions } \\
\text { Perforations }\end{array}\right.$ & $\begin{array}{r}54 \\
2\end{array}$ \\
\hline Anterior chamber & $\left\{\begin{array}{l}\text { Hyphaema } \\
\text { Angle recession }\end{array}\right.$ & $\begin{array}{r}147 \\
3\end{array}$ \\
\hline Iris & $\left\{\begin{array}{l}\text { Iritis } \\
\text { Mydriasis } \\
\text { Dialysis }\end{array}\right.$ & $\begin{array}{r}30 \\
8 \\
1\end{array}$ \\
\hline Lens & Subluxation & 2 \\
\hline Vitreous & $\left\{\begin{array}{l}\text { Posterior separation } \\
\text { Haemorrhage }\end{array}\right.$ & $\begin{array}{l}4 \\
2\end{array}$ \\
\hline Sclera & Perforation & 1 \\
\hline Retina & $\left\{\begin{array}{l}\text { Haemorrhage/oedema } \\
\text { Tear } \\
\text { Detachment }\end{array}\right.$ & $\begin{array}{r}28 \\
3 \\
2\end{array}$ \\
\hline
\end{tabular}

* Details of injury were unrecorded in 34 cases. Thirteen admissions to hospital were known but most were not recorded.

There are well recognised limitations in any reporting system that relies on subjects to complete card reports, and the interest and diligence of the ophthalmologists in this survey to report injuries would have varied. Family practitioners were not consulted in our survey. Despite these admitted limitations our results confirm the impression gained by ophthalmologists that injuries to the eyes during the game of squash have become more common. This first attempt to quantify these injuries does give evidence of their widespread nature, and the total number is probably greater than reported for the reasons mentioned above.

The wearing of eye protectors when playing squash has been recommended by some people and official bodies, 5 and several eyeguards are available commercially. There is, however, no national or international standard for an eye protector. The Squash Rackets Association is examining the evidence on injuries and eye protection in the game of squash

I thank fellow members of the Squash Rackets Association working party, Dr J G P Williams, Mr M Gilkes, and Mr J B Davey. Mr Alan Chalmers, manager of services and administration, Squash Rackets Association, provided the facilities for administrating the survey. I also thank the Faculty of Ophthalmologists for support; Miss Cyrilla Chatfield, who performed all the secretarial work; and the ophthalmologists in England, who reported the cases and made this survey possible.

1 Ingram DV, Lewkonia I Ocular hazards of playing squash rackets. Br f Ophthalmol 1973.57: 434-8.

2 Easterbrook M. Eye injuries in squash: a preventable disease. Can Med Assoc $\mathcal{f}$ 1978;118. 303-5.

3 More MC, Wortheley DA. Ocular injuries in squash players. Australian fournal of Ophthalmology 1977;5:46-7.

4 Mondon H, Lefrancois A, Lai C, Hamard H. Traumatisme oculaire au squash. Bull Soc Ophthalmol Fr 1981;3:81, 303-6.

5 Vinger PF. In: Vinger PF, Hoerner EF, eds. Sports injuries: the unthwarted epidemic. Littleton: PSG Publishing Co, 1981:122.

(Accepted 13 August 1985)

Department of Ophthalmology, St Mary's Hospital and Western Ophthalmic Hospital, London

J L KENNERLEY BANKES, MB, FRCS, consultant ophthalmic surgeon

Correspondence to: Mr Kennerley Bankes, Department of Ophthalmology, Western Ophthalmic Hospital, London NW1.

\section{Humoral antibody response after rubella vaccination}

In five schoolgirls tested after vaccination under the Edinburgh rubella programme all were seronegative by single radial haemolysis, while four were positive by enzyme linked immunosorbant assay. Subsequent specimens from all five were positive by single radial haemolysis. This and other, similar results prompted us to examine vaccinees more closely, particularly with respect to the apparently slow response in antibodies detected by single radial haemolysis. Current interest in extending the British rubella programme towards the Edinburgh system ${ }^{1}$ would involve 
much screening after vaccination, probably by single radial haemolysis. Recognition of the limitations of this otherwise cheap, quick, and effective method would avoid reports suggesting failure of vaccines leading to unnecessary revaccination.

\section{Subjects, methods, and results}

Thirty young adults ( 20 men, 10 women) with no detectable antibodies against rubella were successfully vaccinated with RA27/3 Almevax, Wellcome Medical Division). IgG was estimated by single radial haemolysis, enhanced single radial haemolysis, ${ }^{2}$ and Rubazyme (Abbott Laboratories Ltd); combined IgG and IgM by haemagglutination inhibition; and IgM by three commercially available methods: Rubazyme M (Abbott Laboratories Ltd) and Rubenz M1 and M11 (Northumbria Biologicals Ltd). Eighty four specimens were obtained 17-107 days after vaccination

Ten specimens were collected within three weeks of vaccination. Eight showed IgM but none significant IgG antibodies. Nevertheless, compared with prevaccination serum samples nine showed a positive Rubazyme diagnostic ratio, suggesting seroconversion. IgM was invariably detected at 3-6 weeks; haemag glutination inhibition consistently detected antibody from four weeks, Rubazyme from six, but single radial haemolysis from only seven onwards (table). Before

Detection of rubella antibodies in 84 specimens after vaccination from 30 vaccinees. Blocks showing $100 \%$ positives represent optimum period for detection by each method)

\begin{tabular}{|c|c|c|c|c|c|c|c|}
\hline \multirow[b]{3}{*}{$\begin{array}{l}\text { Days after } \\
\text { vacination }\end{array}$} & \multirow[b]{3}{*}{$\begin{array}{l}\text { No of } \\
\text { pecimens }\end{array}$} & \multicolumn{6}{|c|}{ No of specimens showing detectable rubella antibodies } \\
\hline & & \multicolumn{3}{|c|}{$\operatorname{IgM}$} & $\begin{array}{l}\text { Combined } \\
\text { IgG and IgM }\end{array}$ & \multicolumn{2}{|c|}{$\operatorname{IgG}$} \\
\hline & & $\begin{array}{c}\text { M1 } \\
\text { (no longer } \\
\text { available) }\end{array}$ & $\begin{array}{c}\text { Rubenz } \\
\text { M11 }\end{array}$ & $\underset{M}{\text { Rubazyme }}$ & $\begin{array}{c}\text { Haemagglut- } \\
\text { ination } \\
\text { inhibition }\end{array}$ & $\begin{array}{l}\text { Ruba- } \\
\text { zyme }\end{array}$ & $\begin{array}{c}\text { Single } \\
\text { radial } \\
\text { haemolysis }\end{array}$ \\
\hline $17-21$ & 10 & 6 & 6 & 8 & 6 & & \\
\hline $22-28$ & 7 & & $\uparrow$ & $\uparrow$ & 6 & 3 & 4 \\
\hline $29-35$ & 6 & $100 \%$ & $100 \%$ & $100 \%$ & $\uparrow t$ & 6 & 5 \\
\hline $36-42$ & 13 & 9 & $\downarrow$ & t & & 11 & 6 \\
\hline $43-49$ & 9 & 5 & 7 & $\downarrow t$ & & $\uparrow$ & 7 \\
\hline $50-56$ & 8 & 8 & 8 & 7 & & & $\uparrow$ \\
\hline $57-63$ & 3 & 0 & 0 & 0 & $100 \%$ & & \\
\hline $6+70$ & 8 & 6 & 6 & 5 & & $100 \%$ & \\
\hline $71-77$ & 4 & 1 & 3 & $2 \dagger$ & & & $100 \%$ \\
\hline $78-84$ & 8 & 5 & 5 & $4+t$ & & & 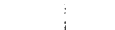 \\
\hline$>84$ & 8 & 4 & 5 & 7 & $\downarrow$ & $\downarrow$ & $\downarrow$ \\
\hline Total & 84 & 57 & 66 & 69 & 79 & 68 & 61 \\
\hline
\end{tabular}

* 30 specimens from vaccinees before vaccination.

†Each mark means one sample was not tested because insufficient serum was available.

seven weeks Rubazyme detected antibodies in nine samples that gave no zones by single radial haemolysis. By enhanced single radial haemolysis seven of these produced zones similar in size to that of a $15 \mathrm{IU} / \mathrm{ml}$ control. Two samples taken 36-42 days after vaccination were negative by Rubazyme and gave no zones by single radial haemolysis and only small zones by enhanced single radial haemolysis. These showed slow IgG conversion as subsequent specimens were positive by all methods.

After vaccination Rubenz $\mathrm{Ml}$ detected IgM less than Rubazyme $M$ and Rubenz M11, which detected similar numbers but not always the same samples. IgM was still detected by at least one method in six of eight specimens taken over 12 weeks after vaccination. Eight vaccinees gave nine specimens $91 / 2-21$ months after vaccination. IgM was present at $91 / 2$ months in one of the "slow responders" but had disappeared by $121 / 2$ months. The seven others were negative.

\section{Comment}

Although haemagglutination inhibition gave early results, the method is time consuming for mass screening, and non-specific inhibitors are a problem. Rubazyme also gave early results but would be expensive for large numbers. For a single, quick result, however, haemagglutination inhibition or enzyme linked immunosorbent assay could be advocated after 3-4 weeks. By single radial haemolysis zones of varying sizes and clarity became apparent from 22 days onwards, but all samples produced zones at least as large as that of standard serum containing $15 \mathrm{IU} / \mathrm{ml}$ only after seven weeks. Mortimer et al reported a delayed response by single radial haemolysis after Cendehill vaccine ${ }^{3}$ and we found a similar delay after Almevax. Enhanced single radial haemolysis can increase sensitivity, but we recommend that Edinburgh schoolgirls are screened two months after vaccination. The slow rather than inadequate single radial haemolysis response in some people was shown by the development of haemolysis zones beyond the $15 \mathrm{IU} / \mathrm{ml}$ control in subsequent specimens.

Rubella IgM was detected in six of eight cases more than 84 days after vaccination and in one after the tenth month. Mortimer et al also detected IgM in 35 of 36 cases at 77 days by anti $\mu$ capture radioimmunoassay, and O'Shea et al reported low concentrations of IgM two, three, and even four years after Cendehill vaccine. ${ }^{4}$ IgM clearly persists in some people, which may cause problems in interpreting results.

This work was supported by a grant for materials from the Lothian Health Board Clinical Research Grants for 1983-4.

1 Cubie HA, Burns SM, Hargreaves FD, Inglis JM, Edmond E, Zealley H. Rubella: immunity and vaccination in schoolgirls. Br Med f 1985;290:1827-8.

2 Champsaur H, Slim A. Rubella vaccine failures. Lancet 1981;ii:47.

3 Mortimer PP, Edwards JMB, Porter AD, Tedder RS, Haslehurst J. The immunoglobulin $M$ response to rubella vaccine in young adult women. $f$ Hyg (Lond) 1984:92:277-83.

4 O'Shea S, Best JM, Banatvala JE, Shepherd WM. Development and persistence of class specific serum and nasopharyngeal antibodies in rubella vaccinees. F Infect Dis 1985;151:89-98.

5 Cubie HA, Edmond E. Comparison of five different methods of rubella IgM antibody testing. $\mathcal{J}$ Clin Pathol 1985;38:203-7.

Accepted 7 A ugust 1985

Regional Virus Laboratory, City Hospital, Edinburgh E10 5SB

HEATHER A CUBIE, MSC, senior virologis

SHEILA M BURNS, $\mathrm{MB}$, CHB, medical registrar

IAN T COLLACOTT, BSC, FIMLS, senior medical laboratory scientific officer LINDA E LAWSON, FIMLS, medical laboratory scientific officer

Correspondence to: Mrs Cubie.

\section{Osteopathic manipulation resulting in damage to spinal cord}

Three cases are described in which osteopathic manipulation resulted in acute spinal cord injury that required surgery.

\section{Case reports}

Case 1-A 56 year old engineer presented to this hospital in August 1984. He had been treated 14 years previously with manipulation for neck pain. Two months before admission, while working under his car, he had experienced pain and Lhermitte's sign in all four limbs. He then developed difficulty in fine finger manipulation and suffered some weakness of both legs. His symptoms worsened with osteopathic manipulation of both cervical and lumbar spines, but the osteopath was unconcerned by this. On admission to hospital he had severe spastic tetraparesis and was unable to walk. Myelography showed compression of the cervical cord, and he underwent anterio cervical discectomy with fusion (Cloward's procedure) at the $C 3 / 4$ and $C 5 / 6$ levels with good result. Six weeks after his operation he was walking well.

Case 2-A 70 year old retired printing manager presented to this hospital in August 1984. In 1978 he had had osteopathic treatment for low back pain. Two months before admission, after lifting a heavy weight, he had experienced more low back pain and left sided sciatica and had received osteopathic manipulation of both the lumbar and cervical spine. The sciatica resolved immediately, but he became unsteady and developed difficulty in fine finger movements. On admission he was unable to walk unaided and had a spastic tetraparesis. Myelography showed an extremely narrow spinal canal that required emergency cervical decompression. Subsequently, he was able to walk unaided.

Case 3-A 64 year old man was admitted to this hospital in January 1985 with a six week history of right lower limb and neck pain. A month before admission he had undergone cervical manipulation that had caused excruciating neck pain. Since that time he had been unable to move his head. On admission the patient was cachectic and clearly in severe pain. Neck movement was impossible. He had a mild tetraparesis and some bilateral sensory loss in his fingers. Plain cervical spine radiographs and computed tomography-myelography showed complete destruction of the $\mathrm{C} 2$ vertebral body with an anterior extradural mass from the clivus to the body of $\mathrm{C} 3$. Chest radiographs suggested a carcinoma of the bronchus. Transoral odontoidectomy and posterior fixation stabilised his neurological state, but he remained in poor condition because of underlying carcinomatosis.

\section{Comment}

In case 2 , apart from a stiff neck, the patient had no clear neurological symptoms, though neurological examination may have resulted in findings consistent with cervical myelopathy. After manipulation by an osteopath, registered with the British Society of Osteopathy, the patient developed severe neurological problems. In the two other cases there were pre-existing neurological symptoms, and manipulation was undertaken by respectable 